\title{
Sonen les trompetes: discurs demodistòpic en el tercer mil.lenni
}

\author{
Andreu Domingo \\ Universitat Autònoma de Barcelona. Centre d'Estudis Demogràfics \\ adomingo@ced.uab.cat
}

\section{Resum}

Amb el nou mil.lenni, els textos, les enunciacions i les declaracions de caire distòpic sobre la població s'han multiplicat i han ultrapassat el camp de la ficció literària. En el present article es planteja una exploració hermenèutica de diferents textos pertanyents tant al camp polític com al científic, on s’identifiquen els principals discursos sobre la població que poden considerar-se distòpics posant un èmfasi especial en els produïts a partir de la crisi econòmica. Es parteix de tres hipòtesis: 1) que les diferents formes d'enunciació, literària (o artística en general), científica o política, deriven d'un mateix imaginari social i s'influeixen mútuament; 2) que la forma distòpica utilitzada per al discurs sobre la població demostra que aquesta continua sent la fi i l'instrument del govern; i, 3) que a partir de la crisi econòmica s'ha precipitat un canvi en el discurs neoliberal sobre la governabilitat que pren precisament la distopia com a marc de referència i reelabora el concepte de resiliència. Paraules clau: demografia; distopia; resiliència; governabilitat; discurs.

\section{Resumen. Están sonando las trompetas: discurso demodistópico en el tercer milenio}

Con el nuevo milenio los textos, las enunciaciones y las declaraciones de carácter distópico sobre la población se han multiplicado y han ultrapasado el campo de la ficción literaria. En el presente artículo se plantea una exploración hermenéutica de diferentes textos pertenecientes tanto al campo político como al científico, donde se identifican los principales discursos sobre la población que pueden considerarse distópicos poniendo un especial énfasis en los producidos a partir de la crisis económica. Se parte de tres hipótesis: 1) que las diferentes formas de enunciación literaria (o artística en general), científica o política, derivan de un mismo imaginario social y se influyen mutuamente; 2) que la forma distópica utilizada para el discurso sobre la población demuestra que esta sigue siendo el fin y el instrumento del gobierno; y, 3) que a partir de la crisis económica se ha precipitado un cambio en el discurso neoliberal sobre la gobernabilidad que toma precisamente la distopía como marco de referencia y reelabora el concepto de resiliencia.

Palabras clave: demografía; distopía; resiliencia; gobernabilidad; discurso. 
Résumé. Au son des trompettes: Discours démodystopique dans le troisième millénaire

Avec le nouveau millénaire, les textes, les énoncés et les déclarations sur la nature dystopique de la population se sont multipliés, dépassant le domaine de la fiction littéraire. Cet article constitue une exploration herméneutique de différents textes appartenant à la fois au domaine politique et au domaine scientifique, où ont été identifiés les principaux discours sur la population pouvant être considérés comme dystopiques, en mettant un accent particulier sur ceux qui voient le jour à partir de la crise économique. L'article est fondé sur trois hypothèses: 1) que les différentes formes d'énonciation littéraire (ou artistique en général), scientifique ou politique proviennent d'un même imaginaire social et s'influencent mutuellement; 2) que la forme dystopique utilisée par le discours sur la population montre que celle-ci est encore l'objectif principal et un bel instrument du gouvernement et, 3) que la crise économique a précipité un changement dans le discours néolibéral sur la gouvernance qui prend justement la dystopie comme cadre de référence, retravaillant le concept de résilience.

Mots-clé: démographie; dystopie; résilience; gouvernance; discours.

\section{Abstract. The trumpets are sounding: Demodystopian discourse in the third millennium}

In the new millennium, dystopian-style texts, pronouncements and declarations about the population have spread and proliferated beyond the bounds of literary fiction. This article takes the form of a hermeneutic exploration of different texts in the political and scientific domains in order to identify the main types of discourse that might be described as dystopian, with particular emphasis on those that have appeared since the onset of the economic crisis. It explores three hypotheses: 1) that the different forms of literary (or artistic in general), scientific or political pronouncements derive from the same social mindset and mutually influence each other; 2) that the dystopian form adopted in discussions about the population continues to be both an instrument and aim of government; and 3) that the start of the economic crisis triggered a change in neoliberal discourse on governability, which has taken dystopia as its frame of reference wherein the concept of resilience is reworked.

Keywords: demography; dystopia; resilience; governability; discourse.

\section{Sumari}

1. Demodistopia: literatura, demografia i governabilitat

2. El creixement de la població

3. Distribució i composició de la població
4. Conclusions: demografia postapocalíptica

Referències bibliogràfiques

\section{Demodistopia: literatura, demografia i governabilitat}

Des d'inicis del segle $\mathrm{xx}$, el creixement de la població i els fenòmens demogràfics (mortalitat, fecunditat i migracions) així com el seu efecte en l'evolució i estructura d'aquesta han esdevingut objecte de ficció. El gènere conegut com a distopia, que explora el pitjor dels mons possibles exagerant les tendències 
negatives que ja són observables (com a inversió de la utopia), es va interessar des de bon començament per la població. Encara que les successives versions cinematogràfiques n'esborressin el rastre, el tema de la població era present a les distopies clàssiques més conegudes: Un món feliç, d’Aldous Huxley (1932), 1984, de George Orwell (1949), o Fahrenheit 451, de Ray Bradbury (1953), per exemple. D'aquesta manera, les distopies que parlen de la població esdevindrien un dels millors exemples del que el demògraf Anton Kruijsten va anomenar "demograficció» (1999) i de molts dels nombrosos textos literaris directament relacionats amb la població (Shriever, 2003). L'anàlisi d'aquelles distopies que tenen com a objecte central la població, que hem anomenat «demodistopies», ens permet seguir els reptes demogràfics i la influència del discurs polític i científic sobre la població en la literatura (Domingo, 2008a i 2008b).

Nascudes arran de l'impacte de l'acceleració del creixement de la població mundial després de la Segona Guerra Mundial, especialment als Estats Units - promogudes per autors com Paul Ehrlich amb el seu Population Bomb (1968) — les demodistopies es van popularitzar ben aviat i van ser dutes a la gran pantalla —un dels darrers exemples pot ser la novel.la de P. D. James, The Children of Men (1992), adaptada al cinema per Alfonso Cuarón el 2006. Durant els darrers anys, el gènere distòpic ha conquerit el públic juvenil utilitzant com a mitjà tant la literatura juvenil com els videojocs. Aquest creixement i canvi de registre es podrien prendre com una trivialització de les distopies en general i de les demodistopies en particular - i de les pors que les fonamenten. Per contra, el que podem detectar, ultrapassats els set mil milions d'habitants, és que la demografia ha tornat a guanyar terreny, sobretot a partir de l'esclat de la crisi econòmica. Apareix com a catàstrofe no premeditada —naturalitzadaperò, tal com ja ho va fer en les demodistopies clàssiques, el seu paper principal és legitimar el model econòmic, en concret, el nou discurs neoliberal que ha profunditzat en la crisi econòmica. Podem posar com a exemple l'informe sobre riscos globals presentat a Davos el gener de 2012 pel World Economic Forum, on les tendències demogràfiques s'anomenaven textualment "gèrmens de distopia» que condicionaven el nostre futur. Però també les declaracions del 22 de gener de 2013 del ministre de Finances japonès, Taro Aso, que demanava a la població anciana que s'afanyés a morir (sic!) per alleujar les finances nipones, o també les tremendistes declaracions del naturalista David Attenborough, el mateix mes de gener, declarant que «els humans som una plaga sobre la Terra» $\mathrm{i}$ instant a controlar més el creixement de la població mundial. Aquest clima va donar prou ales a la literatura perquè el mateix any 2013, el darrer èxit de vendes de Dan Brown, Inferno, abordés el tema. Ja aquí anunciem que la nostra primera hipòtesi de partida és que les diferents formes d'enunciació, literària (o artística en general), científica o política, deriven d'un mateix imaginari social i s'influeixen mútuament. Una espiral que es retroalimenta des del discurs de ficció, científic o polític, que pot ser analitzada com un cas tant d'intertextualitat — com ara la circulació i transformació de petites unitats significatives dotades d'acceptabilitat difusa en una doxa determinada-, com 
d'interdiscursivitat — que concerneix la interacció o influència mútua de les axiomàtiques d'un discurs-, tal com els ha definit Marc Angenot (2010). En una segona hipòtesi, arrisquem que la forma distòpica utilitzada per al discurs sobre la població demostra que aquesta continua sent la fi i l'instrument del govern seguint Michel Foucault (2006), entenent la governabilitat com el conjunt de dispositius de seguretat que asseguren la gestió de la població. La tercera hipòtesi és el supòsit que a partir de la crisi econòmica s'ha precipitat un canvi en el discurs neoliberal sobre la governabilitat que pren precisament la distopia com a marc de referència i reelabora el concepte de resiliència.

Per comprovar aquestes tres hipòtesis, de forma exploratòria hem procedit a l'anàlisi hermenèutica (Gadamer, 1977) de diferents textos pertanyents tant al camp polític com al científic, on s'identifiquessin els principals discursos sobre la població que poden considerar-se distòpics, posant un èmfasi especial en els produïts a partir de la crisi econòmica. Tot i que el nostre interès se centra en el període posterior a 2008, arrenquem abans per millorar la comprensió dels canvis que es generen en el discurs. Així doncs, mostrarem, d'una banda, els discursos demodistòpics que continuen prioritzant el volum de la població com a causa de la catàstrofe i, de l'altra, els que anteposen la preocupació per la distribució i composició d'aquesta, encara que també tinguin en compte la grandària. Per acabar, presentem unes conclusions on debatem sobre la nova naturalesa d'aquest discurs i la relació entre demodistopia i imaginari social.

\section{El creixement de la població}

La desacceleració del creixement mundial a finals del segle xx va provocar que momentàniament la demografia passés a un segon pla en les distopies literàries, desplaçada per la por de les conseqüències del canvi climàtic o de la manca de control sobre l'avenç tecnològic i, en particular, de la biotecnologia. Així, inundacions, sequeres, plagues de virus sintètics i manipulació genètica omplen les planes de les distopies del nou mil-lenni a les obres de T. Coraghessan Boyle (2000), Margaret Atwood (2004 i 2009) o Kazuo Ishiguro (2005). Amb tot, l'evolució de la demografia en general i el creixement de la població en particular continuen apareixent com a font de preocupació tant a la literatura com a la política, preocupació notòriament present entre els ecologistes i els biòlegs i a l'escola neomaltusiana.

Des de la dialèctica entre utopia i distopia, les dues principals vies que continuaran amb la tradició més alarmista dels efectes del creixement de la població se situen als antípodes: d'una banda, la línia ecologista més propera a l'utopisme i, de l'altra, la via neomaltusiana que s'aferma com a posició antiutòpica. Recordem que algunes de les primeres enunciacions de l'ecologisme van ser utopies en tota regla, com, per exemple, Walden or Life in the Woods (1854) de Henry David Thoreau o Ecotopia d'Ernest Callenbach, publicada el 1975, en què, adoptant la forma canònica de les utopies del segle xix, presenta tot un ideari del moviment ecologista, seguida d'Ecotopia Emerging, de 1981. Mentrestant, el neomaltusianisme no necessàriament identificat amb 
l'ecologisme, malgrat expressar la seva inquietud mediambiental, reivindica precisament el maltusianisme com una proposta contra l'utopisme de William Godwin i Nicolas Condorcet fonamentant-se en la filosofia de Karl Popper (1945). Podríem resumir que els discursos desenvolupats per l'ecologisme força diversos - tenen com a objectiu la preservació de la natura, mentre que els neomaltusians economicistes es capfiquen per la preservació del sistema capitalista, tot i que parteixin o instrumentalitzin motius mediambientalistes.

\subsection{Els limits del creixement $i$ la sostenibilitat}

Un dels objectius d'Ehrlich en publicar el seu famós llibre era constituir un grup de pressió a favor del control de la població, que finalment es va concretar en la fundació, juntament amb Richard Bowers i Charles Remington, de la societat Zero Population Growth (ZPG), inspiradora al seu torn del Club de Roma fundat el mateix any 1968. El producte més conegut de l'esmentat club va ser l'informe encarregat al MIT i realitzat per Donella H. Meadows i altres col-laboradors, The limits to Growth, el 1972. Aquest tipus de perspectiva va engendrar tota una tradició. Si el mateix Paul R. Ehrlich i la seva esposa Anne Ehrlich van reactualitzar les catastrofistes previsions l'any $1990 \mathrm{amb}$ The Population Explosion, i també l'equip de Donella Meadows i el seu marit Dennis Meadows i Jorgen Randers van fer el mateix amb l'informe sobre els límits del creixement, els anys 1992 i 2004, no han mancat seguidors de la seva línia basats exclusivament en el creixement de la població.

Un bon exemple d'aquesta branca de pensament és l'obra de Giovanni Sartori i Gianni Mazzoleni, amb l'eloqüent títol La Terra explota. Superpoblació $i$ desenvolupament, publicat el 2003, que arrenca amb la hipòtesi que Ehrlich es va equivocar només en l'horitzó de les seves previsions, però no pas en l'anàlisi de les conseqüències de la superpoblació i de com actuar contra aquesta. L'actualització dels arguments del biòleg i mediambientalista significa el retorn a la lògica de l'enfrontament entre desenvolupistes i maltusians que havia caracteritzat el debat sobre el creixement de la població i la teoria de la transició demogràfica des de Frank Notenstein (1945), com a mínim fins al Congrés Internacional de Població de Mèxic el 1984, afegint a sobre el deteriorament mediambiental a les raons aportades tradicionalment pel neomaltusianisme. S'ha passat de posar l'accent en el suposat dèficit de productivitat i la crisi alimentària al consum energètic com principal espasa de Dàmocles que penja sobre el futur de la humanitat.

La forma més efectiva per fer disminuir el consum serà, segons aquests autors, reduir la població. Una de les proves principals n'és l'existència d'un punt de no-retorn des de l'òptica mediambiental, a partir del qual l'excés de població destrueix les condicions de vida del planeta $\mathrm{i}$ aboca la humanitat a la seva extinció. Es destaca els límits de la tecnologia per esdevenir una solució quan és part essencial del problema. Com el mateix Ehrlich, la posició de l'Església catòlica esdevé el blanc de les crítiques, com també les organitzacions internacionals com la FAO, que, segons els autors, han cedit a les pressions dels 
grups de pressió energètics que conspiren per silenciar l'evidència de l'amenaça demogràfica. La referència al Club de Roma i al primer informe de 1972 situa els autors en l'escenari distòpic, que Meadows i els seus col-laboradors semblen haver temperat en la darrera versió.

Per acabar, volem destacar que al treball de Sartori i Mazzoleni ja s'insinua el discurs sobre la seguretat que es desenvoluparà en els autors que es fixen més en els efectes de l'estructura i que veurem més endavant. Aquesta preocupació per la governabilitat se sintetitza en l'afirmació que, com més greu és l'escassetat mediambiental, més gran és la turbulència social que se'n deriva, i menor la probabilitat que la societat pugui produir la regeneració necessària per adaptar-se. Participen de la por a la massa i a la revolta social que havia animat demodistopies com 1989: Population Doomsday, de Don Pendleton, de 1970, o The Edict, de Max Ehrlich, de 1972. El desenvolupament dels arguments dels sociòlegs i economistes italians no l'hauríem de buscar en aquestes fonts, clarament tenyides de conservadorisme. La por també s'ha d'entendre com la reacció a l'agitació social en la contestació a la globalització que va envoltar les manifestacions contra la cimera de l'Organització Mundial de Comerç celebrada a Seattle el 1999, i la contracimera de la reunió del G8 convocada a Gènova el juliol de 2001.

\subsection{De la utopia a la distopia ecologista}

La mirada ecologista, que en principi veia el creixement de la població com una amenaça per a l'equilibri dels sistemes ecològics, ha evolucionat per projectarse bàsicament com un esforç de restitució: el mal ja està fet, la humanitat ha esdevingut una pesta. Al voltant d'aquesta metàfora giraran algunes de les demodistopies literàries més reeixides (Lionel Shriver, 1994) i de les que se situen directament dins la militància ecologista (Colin Macpherson, 1999). La darrera actualització del tema és el ja esmentat Inferno (Dan Brown, 2013).

Entremig, les al-ludides declaracions dels naturalistes més mediàtics, com David Attenborough i la seva tesi sobre la humanitat com a plaga, que insta a controlar més el creixement de la població mundial, tradueixen la posició bel.ligerant de l'ecologisme. Posicionament que es popularitza a través dels documentals sobre la natura i que es manifesta recurrentment. Valguin com a exemple les declaracions en aquest sentit del conegut comandant Cousteau, més de vint anys abans (Cousteau, 1991), clamant no per la limitació, sinó per la reducció dràstica de la població humana. La mirada ecologista tendeix a veure els humans com una arna voraç que ha destruït l'equilibri natural i que acabarà portant-nos a tots plegats a l'extinció.

Com a exemple d'aquest discurs sobre la població hem triat l'obra del geofísic James Lovelock, desenvolupada des de finals dels anys seixanta a partir de la teoria de Gaia, que tracta el planeta Terra com un sistema evolutiu autoregulat. Aquí només tractarem el discurs en aquells aspectes que afecten directament la relació del creixement de la població i la interacció dels humans amb Gaia en les seves darreres formulacions. El punt de partida és maltusià, via 
el matrimoni Ehrlich: això no ens ha de sorprendre, si tenim en compte que les seves primeres elucubracions sobre la hipòtesi de Gaia són contemporànies a la publicació de Population Bomb. L'interessant de la visió de Lovelock en matèria demogràfica és que, xifrant l'òptim de població al voltant dels mil milions d'habitants quan s'han superat els sis mil milions, tot el desplegament retòric donarà voltes a la idea de restitució en el primer volum publicat al nou mil.lenni (2004), The revenge of Gaia, mentre que en el segon, The vanishing face of Gaia, de 2009, prop dels set mil milions, ja dóna per impossible la restauració de l'equilibri, ni que es prenguessin mesures immediates.

En el primer dels volums esmentats, com dèiem, encara creia que era possible escapar d'un escenari distòpic provocat pel creixement incontrolat de la població, tot i que criticava la tesi sobre el "creixement sostenible», impulsada pel Club de Roma i que ha passat a ser hegemònica, com una fal.làcia abonada pels grups de pressió energètics. Defensa la necessitat d'aprendre a decréixer i proposa, a més, passar del control de la fecunditat a actuar sobre l'esperança de vida (contenint-la als cent anys, per començar). Per poder aplicar amb urgència les mesures que es necessiten per contenir l'efecte hivernacle, $i$ amb aquest el control de la població, formula una alternativa inquietant, repetidament explorada per les distopies literàries dels anys setanta: la suspensió temporal de la democràcia i l'aplicació de l'estat d'excepció, i desenvolupa tota una retòrica bel-licista en la seva argumentació: "Can the present day democracies, with their noisy media and special-interest lobbies act fast enough for an effective defence against Gaia? We may need restrictions, rationing and the call to service that were familiar in war time and in addition suffer for a while a loss of freedom» (Lovelock, 2006: 196-97).

Com hem dit, la segona publicació, de 2009, és més pessimista: el retorn ja és impossible. L'avançat estat de degradació mediambiental fa que l'adaptació a la catàstrofe sigui l'estratègia recomanada. Hauríem d'haver actuat més rigorosament als anys setanta, quan el crit d'alerta d'Ehrlich va fer públic el problema del creixement de la població, es lamenta. Des que la humanitat va desenvolupar la tecnologia, els humans van significar per a Gaia una infecció, que hauria romàs en estat d'incubació fins al salt qualitatiu del seu creixement exponencial a causa de la industrialització. Ara vivim el temps de l'agonia. Haurem de canviar l'estil de vida, renunciar a les indústries contaminants i impulsar l'energia nuclear — segons l'autor, una de les més eficients i menys contaminants-, limitar la ramaderia (per les emissions de metà) i imposar el vegetarianisme. Però fins i tot adoptant aquestes mesures, ja és tard. Què es pot fer, doncs?

A partir d'aquí desenvolupa tot un discurs sobre la governabilitat que, com veurem, entroncarà directament amb les propostes que trobarem en el discurs sobre la seguretat. Es tracta, escriu, de pensar les mesures per a un món de supervivents, i amb aquestes, un cert tipus de governabilitat. El tema de qui són els supervivents i de com se seleccionaran es deixa sentir com un corrent d'aire subtil però tan gèlid que eriça els pèls del clatell de l'astorat lector. Res no és obertament proclamat, només insinuat, potser perquè no resulta moralment acceptable..., encara? Tres són les propostes principals: suspensió temporal de 
la democràcia — posa com a exemple l'acceptació a la Gran Bretanya, l'any 1939, de l'estat d'excepció-, lideratge i retorn al dogma (a una representació de creences que prioritzi el medi ambient, que es mogui en un terreny compartit entre la ciència i la religió). Quines implicacions pràctiques té aquest pla? Abans d'exposar-les, haurem d'advertir que el volum es dirigeix al públic anglosaxó i que, segons els càlculs de Lovelock sobre l'efecte de l'escalfament global, la Gran Bretanya és una de les poques regions que es pot lliurar de la desertificació. A partir d'aquesta darrera premissa, llança una proposta aïllacionista i regressiva, que ell mateix qualifica de tribalista: la Gran Bretanya és una nau que milions de refugiats ecològics voldran assaltar. La primera cosa que cal fer és desprendre's del llast que representa ser membre de la Unió Europea, però també de qualsevol altra institució internacional, apostar per una escalada armamentista per defensar la supervivència dels britànics —en la qual veu l'oportunitat d'accelerar l'evolució tècnica que trobi una solució als reptes mediambientals en què ens trobem-, i, finalment, tornem al tema de la selecció, d'aquests refugiats ecològics que voldran assaltar el vaixell. Sense resoldre aquesta qüestió, acudeix a l'analogia de la migració clandestina des de l'Àfrica fins a les costes de les illes Canàries, per afirmar que l'esperit de superació i la tria que efectivament es dóna en una travessia d'aquest tipus ja actuen com una selecció natural (sic!), i es malfia de la planificada. Es pot imaginar un horitzó més distòpic?

La darrera contribució a aquesta perspectiva i una de les més desesperançades és l'al-legat de Stephen Emmott, director de Ciències Informàtiques a Microsoft Research, amb el seu Ten Billion, una mena de memoràndum on desgrana el seu escepticisme quant a corregir el rumb cap a la catàstrofe a la qual el creixement de la població ens mena. Els arguments són similars als que ja hem vist en la línia ecologista: ja s'ha fet tard, no es tracta de la distància entre el creixement de la producció i el de la població, es tracta de fer front al consum desaforat, no es veu la possibilitat d'aplicar mesures ni tècniques, ni un canvi d'estil de vida que redueixin el consum el que fos necessari. La principal conseqüència resulta molt similar a l'exposada per Lovelock: la militarització del primer món per defensar-se de les migracions provocades pel canvi climàtic. El que és nou és l'acusació directa als polítics de manipular l'opinió pública i presentar-los com una de les parts importants del problema, i denunciar el divorci entre el que es diu i el que es fa. Només resta preparar-se per a la supervivència en un món enfonsat en la violència.

\section{Distribució i composició de la població}

Un cop acceptada la premissa de la desacceleració del creixement de la població, la pèrdua de pes específic del món desenvolupat en termes relatius - específicament d'Europa - obre les portes a un replantejament de la geopolítica basada en les tendències de l'evolució demogràfica, i amb aquesta creix la importància de la distribució de la població i de la seva composició (principalment per sexe i edat, i per l'increment de la diversitat poblacional a causa 
de les migracions). El marc conceptual que intenta adequar la governabilitat en el temps de la globalització és el discurs de la seguretat i la societat del risc. S'estableix l'axioma que com més complex es torna el sistema, més gran és el risc global i la necessitat d'actuar preventivament sobre aquest.

Aquest marc de la societat del risc, terme encunyat pel sociòleg alemany Ulrich Beck el 1986, feia referència a l'anticipació de la catàstrofe i la corresponsabilització entre l'estat i els individus, on l'estat assumia la contenció previsora i la distribució «justa» de les conseqüències i els costos derivats de les decisions individuals. En aquest sentit, podia considerar-se que derivava d'una ontologia distòpica, on l'anticipació de la catàstrofe ens pot lliurar d'aquesta i esdevenir un reclam imperatiu per a la intervenció. Una dècada més tard, veuríem com aquesta via utòpica quedaria substituïda per la pitjor de les distopies. La transformació del discurs és inseparable dels canvis polítics: començant per l'ascensió fulgurant de la prèdica neoliberal després de l'anomenada crisi del petroli, fins a la caiguda del mur de Berlín el 1989, que va portar alguns a parlar de la «fi de la història» com a metàfora del triomf indiscutible del capitalisme (Fukuyama, 1989).

\subsection{Seguretat: la petja de Huntington}

Un dels precedents més influents i coneguts d'aquesta perspectiva distòpica va ser el politòleg Samuel Huntington amb la seva tesi Clash of civilizations (1993 i 1996). Aquesta visió — que no ens entretindrem a descriure, ja que s'ha fet prolixament - va suposar la substitució de la geopolítica basada en l'enfrontament est/oest per una nova lògica que prioritzava l'eix nord/sud. Si la primera oposició es podia considerar simètrica —amb un tercer món percebut com el tauler d'escacs de l'enfrontament entre les dues superpotències-, la segona, que proposa un escenari igualment dualitzat entre nord i sud però asimètric, disposa de diferents centres de conflicte entre el que l'autor qualifica de «civilitzacions». És el que ell mateix sintetitza com la substitució del teló d'acer de les ideologies pel teló de vellut de les civilitzacions, en resposta al triomfalisme de Francis Fukuyama. La demografia pren protagonisme en tres aspectes: 1) el creixement diferencial de les poblacions tant a la política internacional —que marcaria la relació entre les anomenades «civilitzacions»—, com a la domèstica, entre els grups a l'interior de les societats - amb les anomenades «minories»-; 2) la interpretació problematitzada de les estructures per edat, envelliment al nord i excés de joves al sud; i 3) el paper negatiu, o com a mínim sota sospita, que recau sobre les migracions (que nodreixen les minories). Els tres temes es perpetuaran en el pensament distòpic portat a la política impulsada pel neoliberalisme bel.licista de l'administració Bush fill. Fins i tot les campanyes militars es tornen preventives.

A nosaltres ens interessa com aquesta visió distòpica es basa en les projeccions demogràfiques. L' «I si...» fa que la catàstrofe es faci present: occident minoritzat; l'envelliment com a metàfora biologicista de la pèrdua d'empremta dels països; el tema de l'esfondrament del sistema de pensions a causa del 
decreixement de la proporció d'actius (animat pels bancs i les asseguradores d'arreu del món); o la joventut vista com a focus de turbulència (concretament com a protagonista de l'auge de l'extremisme islàmic fins a l'any 2033, en què es preveu una caiguda del pes dels joves al món musulmà). En el camp de les migracions, destaca la seva insistència en la minorització de la població blanca (i protestant) als Estats Units causada principalment per l'augment dels hispans (2004).

La conflictiva visió de Huntington va convergir amb la del demògraf JeanClaude Chesnais, que el 1995 havia publicat Le crépuscle de l'Occident. Démographie et politique. Malgrat que el discurs del francès bevia a les fonts històriques pronatalistes gal.les, coincidien a fer un problema de la nova distribució de la població mundial amb la progressiva pèrdua de pes dels països desenvolupats —especialment els europeus en el cas del demògraf_, i la composició de la població, sobretot pel que fa als comportaments demogràfics diferencials d'immigrats i nacionals: la qual cosa porta a primer terme el tema de la desnaturalització (ja present en els debats eugenistes dels anys trenta arreu del món). Per a Chesnais, la baixa fecunditat dels països desenvolupats, responsable al seu torn de la creixent immigració i de l'acceleració de l'envelliment, condemna aquests països a la fragmentació ètnica i a l'agonia demogràfica. En clau francesa, no deixa passar l'ocasió per atacar els postulats del que ell anomena neoecologisme antihumanista per referir-se a l'abans citada demanda de J. Y. Cousteau de limitar la població humana (fent-la retrocedir), que xoca frontalment amb el seu discurs natalista.

El nou ordre mundial proposat a les tesis de Samuel P. Huntington i l'increment de les migracions durant els primers anys del segle XXI, com també l'obra de Chesnais, han servit d'argumentació als moviments d'extrema dreta en alça a les democràcies liberals, com molt abans (el 1973) ho havia fet la demodistopia racista de Jean Raspail Le Camp des Saints — citada com a font d'inspiració per Huntington-, on es defensa el «legítim ús de la violència» de la societat francesa (blanca) assetjada per la pobresa encarnada en els immigrants del tercer món (desarmada i pacífica). El 2004, amb una campanya d'articles a la premsa, Raspail renova els seus raonaments i explicita el rerefons ideològic alertant sobre una suposada ocultació per part de l'Institute Nacional d'Études Demographiques (INED) dels resultats de les projeccions de població que demostraria l'irreversible procés de minorització i desaparició de la població francesa - cal entendre de la població francesa de soca-rel_- utilitzant el model de la Reconquesta espanyola, llibret també utilitzat per Anders Breivick, autor de la massacre d'Utoya el juliol de 2011 i que va escriure la distopia 2083 A European Declaration of Independence.

La petja de les tesis de Huntington en matèria de població és recognoscible en l'extrema dreta i fins i tot en aquells que en discrepen o se li oposen obertament, sobretot en el camp de la politologia. Així, el vincle entre transició demogràfica i discurs sobre la seguretat, en el marc d'un futur marcat per l'enfrontament policèntric, passa a ser central per a alguns autors, com Richard P. Cincotta (Cincotta, Engelman i Anastasion, 2003; Cincotta, 2004). 
L'increment de conflictes i de les seves dimensions des de la segona meitat del segle Xx s'imputa directament als països que es troben al bell mig de la seva transició demogràfica i disminueix al mateix ritme que ho fa l'índex sintètic de fecunditat, de manera que es fa responsable la població de les desigualtats econòmiques que rauen a l'arrel d'aquests conflictes. Per il.lustrar-ho contraposen la situació entre alguns països el sud-est asiàtic, on la fecunditat ha baixat ostensiblement (Corea del Sud, Tailàndia, Singapur o Malàisia) amb d'altres on els nivells encara són alts (Iraq, Afganistan o Nigèria). Entre els factors de risc purament demogràfics que amenacen la seguretat en destaca vuit: 1) les altes proporcions de joves entre 15 i 29 anys; 2) el ràpid creixement urbà; 3) els baixos nivells per càpita de terra destinada a l'agricultura o d'aigua potable; 4) l'alta mortalitat entre la població en edat activa (especial referència a la sida); 5) el creixement diferencial entre grups ètnics i religiosos; 6) la migració; 7) l'envelliment i el declivi de la població; i 8) desequilibri dels efectius per sexes (on els homes sobrepassen les dones). En termes de seguretat, doncs, les tendències demogràfiques més destacades de tots els països són sistemàticament percebudes com a amenaces, sigui quina segui la fase en què es troben dins la seva transició demogràfica.

\subsection{Societat del risc: de la prevenció a la resiliència}

A partir de la recent crisi econòmica i la presa de consciència de la pujança dels anomenats països emergents, la proposta neoliberal es transforma radicalment $\mathrm{i}$ fa eclosionar un discurs que s'havia anat covant molt abans. Seguim en el marc general de la seguretat i la societat del risc, però s'ha produït un desplaçament del concepte de "prevenció» al concepte emergent de "resiliència», com ha assenyalat el geògraf Ash Amin (2012). En lloc de l'economia del benestar, que emfasitzava l'accés al progrés econòmic i la distribució equitativa dels seus fruits, la nova lògica considera les poblacions i els individus des del punt de vista més estret de la seva contribució a una competència mundial i al seu cost, precisament minada des de l'anterior crisi de 1973 i l'embranzida que van prendre les polítiques desreguladores dels governs neoliberals. Atacs terroristes (Nova York, 11 de setembre de 2001; Madrid, 11 de març de 2004; Londres, 7 de juliol de 2005), catàstrofes naturals (el tsunami que va arrasar les costes del sud-est asiàtic el desembre de 2004, l'huracà Katrina l'agost de 2005 a Nova Orleans, l'erupció d'un volcà islandès l'abril de 2010 i la crisi nuclear provocada per l'assot d'un tsunami a les costes japoneses el març de 2011) i els efectes de la crisi del sistema financer per la caiguda de Lehman Brothers el 2008 han precipitat aquest canvi de discurs.

Afermada en la multiplicació dels riscos i en la seva curta predictibilitat, dins el context d'aquesta nova lògica, entenent que els riscos són inevitables i és preferible adoptar estratègies de minimització i mitigació en comptes de les de prevenció i evitació, s'implementa el concepte de resiliència, definit genèricament com la capacitat de resistir els obstacles i recuperar-se'n. Aquests concepte, procedent de la física i utilitzat per l'enginyeria i l'arquitectura, va 
néixer aplicat a materials i construccions per calcular estructures, però aviat va passar a altres camps científics (medicina, biologia o ecologia, per exemple), aplicat a sistemes complexos adaptatius que van des del mateix individu fins a les nacions o la totalitat del planeta. Ha estat definit com: «That has the capability to 1) adapt to changing context, 2) withstand sudden shoks and 3) recover to a desired equilibrium, after the previous one or a new one, when preserving the continuity of its operations» (World Economic Forum, 2013). Aquest traspàs de la prevenció a la resiliència exemplifica la modificació radical del mode d'exercici del poder governamental, així com de les referències doctrinals que acompanyen el canvi de les regles del capitalisme, com han assenyalat Christian Laval i Pierre Dardot (2010). Per tant, té efectes en la manera de percebre la població en la seva dinàmica i estructura. Volem assenyalar de forma especial la translació des de l'ecologia (i l'estudi de les poblacions animals) fins a la demografia i la sociologia. D'aquesta manera, la resiliència, aplicada a un sistema ecològic o a una espècie determinada, introdueix l'efecte d'esdeveniments inesperats en l'equilibri de diferents poblacions animals (Holling, 1975), considerant tant la discontinuïtat temporal com l'heterogeneïtat espacial i aportant una mirada també positiva a partir de la noció d'estabilitat. Entesa així, la resiliència pot ser el producte adaptatiu a les fluctuacions més o menys atzaroses que pertorben l'equilibri.

Un dels màxims exponents d'aquesta perspectiva aplicada a l'evolució de la població com a risc en relació amb la geopolítica és l'anàlisi aportada pel politòleg Jack A. Goldstone i el seu article «The New Population Bomb» (2010). En aquest article, prenent l'obra dels Ehrlich i la de Huntington com a referència, uns quinze anys més tard de la publicació de Crash of Civilisations, ens proposa passar de la dicotomia nord/ sud al retorn a una estratègia a tres bandes seguint les característiques demogràfiques dels països. D'aquesta manera, distingeix entre els països desenvolupats (caracteritzats per l'envelliment de la població), els emergents (que momentàniament treuen avantatge de la finestra d'oportunitats que brinda una estructura demogràfica caracteritzada per la gran quantitat d'actius en relació amb l'escassa proporció de dependents, vells i infants), i, finalment, els més pobres (amb un excedent de població jove sense educació i un mercat de treball incapaç d'absorbir-la). Alguns d'aquests elements, com hem vist, recorren a vells arguments o els redefineixen, com per exemple la por als joves, que es confon amb la por a les masses -i que l'autor utilitza per explicar l'esclat de la Primavera Àrab—, o la fragilitat de l'estat, amenaçat per la demografia. D’altres són completament nous: la integració com a agents polítics internacionals dels països emergents, trencant completament les tesis de Huntington i recomanant la inclusió de Turquia a la UE, el reconeixement de la centralitat del G-20 (en comptes del G-8) o l'ampliació de l'OTAN, més enllà dels països «occidentals». Amb tot, la novetat més important no és esborrar les fronteres de les suposades civilitzacions com a línies d'enfrontament, sinó capgirar el paper de les migracions des del punt de vista de la «seguretat». De la imatge de problema que tenien Huntington o Chesnais es passa a presentar-les com la solució: «Correctly managed, population move- 
ment can benefit developed and developing countries alike. Given the dangers of Young, underemployed, and unstable populations in developing countries, immigration to developed countries can provide economic opportunities for the ambitious and serve as a safety valve for all» (Goldstone, 2010). És a dir, no és raonat en termes dels beneficis econòmics que en poden extreure els països receptors de la immigració, sinó en termes de seguretat.

Amb els informes del World Economic Forum de Davos sobre Global Risks, 2012 i 2013, podem entendre millor el viratge de la prevenció a la resiliència, i això utilitzant explícitament el marc de la distopia. En el mateix informe de 2012, l'impacte del creixement de la població i dels canvis en la seva distribució i composició s’analitza segons la mateixa divisió que ja hem vist amb Goldstone, posant en relació el grau de desenvolupament econòmic i l'etapa de la transició demogràfica en què es troben. Cadascun dels tres grups de països s'enfronta a riscos poblacionals diferents o als mateixos riscos, que es tradueixen de forma diferent. Així, per als països del primer grup, els desenvolupats que es troben en la fase posttransicional, el risc principal és l'envelliment de la població i l'envit que representa per a la sostenibilitat del sistema de pensions, que augmenta la fragilitat de l'estat, però també les polítiques d'austeritat, que estan creant una base de joves preparats i creixentment frustrats a mesura que veuen com desapareixen les seves oportunitats. En les economies emergents, que s'aprofiten de la conjuntura demogràfica beneficiosa que representa l'anomenada finestra d'oportunitats deguda a la proporció d'actius amb una minvada proporció de dependents, el principal problema és, juntament amb el fet de satisfer aquesta demanda d'ocupació, la visibilitat de l'abismal desigualtat econòmica que el creixement actual no fa res més que aguditzar i que pot traduir-se en inseguretat ciutadana i repte a l'estat en forma de protestes socials. Finalment, tenim els països més pobres o pretransicionals, on el creixement del nombre de joves sense esperança d'ocupació i amb nivells de formació limitats a un sector reduït amenaça la pròpia viabilitat dels seus estats. Concretament podem parlar dels casos de l'Afganistan, el Pakistan, Timor Oriental i la majoria dels països subsaharians.

En aquest context, la migració, també com diu Goldstone, apareix com el nexe d'unió demogràfic entre les diferents regions (poblacions) però alhora com la solució. Això de dues maneres: 1 . Es defensa que les migracions conseqüència de la urbanització intensiva haurien produït les millores en el sistema de formació i, per tant, en les habilitats tecnològiques dels joves. 2. Juntament amb l'adquisició d'aquestes habilitats es produiria l'aprenentatge de l'actitud correcta (sic!), és a dir, de la filosofia de l'emprenedoria, del saber fer. Predisposició que podem traduir com a hàbit neoliberal, en el sentit que li atorga Pierre Bourdieu com a sistemes d'esquemes de percepció, apreciació i acció que delimiten actes de coneixement pràctic —en la taxonomia i reconeixement-, a partir dels quals es despleguen estratègies circumscrites a les estructures de les quals són producte i les defineixen (Bourdieu, 1997); que el neoliberalisme necessita les noves generacions, seguint la tesi de Christian Laval i Pierre Dardot, abans esmentat. És clar que, per a les migracions internacionals, el que 
s'haurà de buscar són els canals legítims per satisfer la demanda del mercat, segons l'informe. L'evolució demogràfica prevista tant en l'acceleració de la urbanització com en els canvis d'estructura (envelliment d'un estat o manca o excés de joves) es conjuga amb l'impacte de les polítiques d'ajustament per constituir dos riscos distòpics que amenacen directament la governabilitat: el descontentament i la frustració que cova l'anomenada "generació perduda», referint-se als joves mancats d'oportunitats per entrar al mercat de treball, malgrat la seva preparació, però també a la «desconcertant sensació» — segons els autors de l'informe- de la mobilitat social descendent que plana sobre àmplies capes de la societat i que acompanya el creixement de la desigualtat econòmica, que amenaça amb desordres socials i repta els estats incapaços de revertir aquesta situació.

Com es poden evitar aquests riscos per a la seguretat? Aquí és on apareix la migració com a solució. Una política migratòria adequada, se’ns diu, pot alleujar la tensió social alhora que satisfa les demandes del mercat. Aquest canvi radical es confirma en l'edició de l'any 2014 de l'informe sobre riscos globals (World Economic Forum, 2014), on les restriccions a les migracions juntament amb el fracàs dels estats i les entitats supraestatals a promoure sistemes més inclusius per a la població immigrada és el que s'assenyala com el perill més gran per a l'estabilitat política dels pròxims anys. La introducció a l'agenda de la Unió Europea per al 2015 de la «mobilitat», centrada en la migració de joves com a objectiu prioritari, pot considerar-se la culminació d'aquesta agenda. La segona solució, l'haurem de trobar en un lideratge nou: invertir en mecanismes de poder que forneixin la població de les habilitats necessàries per fer front als riscos que s'apropen. Com? Augmentant la resiliència! Així, la segona part de l'informe es dedica a l'anàlisi de les conseqüències que va tenir en la governabilitat el terratrèmol del març de 2011 al Japó. Les catàstrofes naturals a les quals s'assimilen el terrorisme i el crim en la seva versió virtual justifiquen un lideratge nou, però alhora una nova actitud dels governats, goodfollowship, definida com: "the capacity to avoid two extreme forms of group behaviour - excess conformity and excessive conflict- that can impede the capacity for effective crisis response» (World Economic Forum, 2012). L'informe de 2013 conté tota una secció sobre la construcció de la resiliència davant dels riscos globals. En fer balanç de l'increment dels riscos respecte de l'any anterior, en l'apartat demogràfic només assenyalen dos factors: retorn al creixement de la població i a la gestió de l'envelliment. Ni una paraula sobre les migracions. Però, per entendre millor cap a on s'orienta aquesta interpretació dels riscos globals - només cal fer una ullada a la resta de riscos, agrupats en tecnològics, econòmics i geopolítics-, es destaca per aquest ordre: unforeseen consequences of new life science technologies and unforeseen consequences of climate change; unforeseen negative consequences of regulations, hard landing of emerging economy and chronic labour market imbalances; per acabar, unilateral resource nationalization. És a dir, tot allò que amenaci el capitalisme directament (regularitzar el mercat i les nacionalitzacions) $\mathrm{i}$ indirectament, pel malestar social que pot generar (l'augment de l'atur), la resposta vehiculada pels mitjans de 
comunicació o, simplement, el col-lapse causat pel creixement antiecològic (Word Economic Forum, 2013: 48).

\section{Conclusions: demografia postapocalíptica}

Si la distopia clàssica podia considerar-se un crit d'alerta per evitar un futur indesitjable, la perspectiva de la resiliència significa un gir de 180 graus i situarse en escenaris postapocalíptics: ja no es tracta d'evitar la fi dels temps, sinó de sobreviure a l'Armagedon. Les trompetes del judici ja sonen i el pitjor és quedar-se fora del futur. Convertir-se, segons la perspectiva del mercat, en població excedent, prescindible. El model biològic comporta no només una naturalització del discurs neoliberal, més que evident, sinó també la integració de la redundància com a estratègia resilient, que, observada en algunes espècies, s'assimila primer a les empreses i per extensió a la societat.

Podem identificar diferents factors que expliquen el retorn als discursos demodistòpics durant el nou mil.lenni: en primer lloc, la correcció a l'alça de les hipòtesis mitjanes de les projeccions fetes per la Divisió de Població de les Nacions Unides. En segon lloc, la mateixa institucionalització de l'alarmisme sobre el creixement de la població, encara que sigui amb negacions retòriques, animada per la necessitat de la Divisió de Població de captar més fons i, amb aquests, més atenció mediàtica. Per acabar, però per a nosaltres més rellevant, la crisi econòmica i el nou model de governabilitat impulsat pel neoliberalisme, exemplificat en el discurs dels màsters de l'univers de Davos, que troben, com sempre han fet, en la demografia la coartada perfecta per imposar més facilment el seu projecte disciplinari i exonerar l'economia de la degradació del medi ambient i distreure la nostra atenció de la creixent desigualtat econòmica que provoca.

Aquest segon retorn, però, produeix una certa inquietud en la seva voluntat d'instal.lar-se com a topos i nou horitzó que recull el feix de possibilitats que conformaran el futur: és a dir, el que és plausible però alhora acceptable, tal com es desprèn de la utilització del discurs polític. De la transgressió que la distopia va representar en crear un camp d'enunciació per a l'impensable, s'ha passat a una situació en què es legitima i es crea un espai de possibilitats per al que era refusat com a impossible per intolerable, moralment parlant, començant per la deslegitimació de la democràcia. Les demodistopies dels anys setanta, centrades en els perills de l'explosió de la població mundial, havien servit en el temps del desenvolupament econòmic per presentar l'escassetat com un problema demogràfic i no com un problema de redistribució de la riquesa, essencialment econòmic. El pensament demodistòpic al segle XXI mostra la recurrent fricció entre capitalisme i democràcia, on les exigències del mercat posen en dubte la viabilitat del sistema democràtic (Streeck, 2011), com el resultat de l'excepcionalitat creada per la catàstrofe — no únicament demogràfi$\mathrm{ca}-$, que reclama un nou lideratge a imatge i semblança de la gestió neoliberal.

El que resulta preocupant és que la distopia ja no apareix com el joc literari que ens permet denunciar l'impronunciable, sinó com una mutació possible que emergeix de l'ebullició del discurs social. És a dir, el que busca un lloc i, per tant, 
la seva realització, establint un espai de credibilitat nou, no una eutopia, sinó un topos concret. L'imaginari social exigeix la realització material. L'excentricitat d'algunes de les enunciacions esmentades no poden ser reduïdes a la futilitat de l'estirabot, entenguem-nos, a la inoportunitat individual, gens representativa del discurs social hegemònic. Per a nosaltres podrien esdevenir el signe d'una ruptura discursiva, que emergeix com heteronomia, que prepara el terreny de l'acceptable en l'escenari postapocalíptic de la distopia neoliberal. Els científics i els polítics amb discursos catastrofistes recorren els camins ja transitats dels laberints propis de les distopies literàries. Les solucions lògiques que apliquen, més que inspirades en lectures distòpiques en la infancia, s'han de considerar el resultat d'un exercici ja prèviament realitzat pels escriptors del gènere a la segona meitat del segle XX. El que per a uns era profecia, per als altres encara es movia en el terreny de la provocació, del «risible». Ni Bioy Casares (1969), ni Kurt Vonnegut (1953 i 1968), en les seves distopies protagonitzades per vells i la vellesa, haurien imaginat les declaracions televisades del ministre de Finances japonès, Taro Aso. Però el que a la literatura de ficció pot ser confortablement aterridor, en la política i la ciència resulta paorós.

\section{Referències bibliogràfiques}

Amin, Ash (2012). Land of Strangers. Cambridge: Polity Press.

Angenot, Marc (2010). El discurso social. Los limites históricos de lo pensable y de lo decible. Buenos Aires: Siglo XXI.

Aтwоod, Margaret (2004). Oryx and Crake. Nova York: Anchor Books.

- (2009). The Year of the Flood. Nova York: Doubleday.

Augé, Marc (2008). Où est passé l'avenir? París: Éditions du Panama.

BECK, Ulrich (2008). La sociedad del riesgo mundial. Barcelona: Paidós.

Bioy Casares, Adolfo (1969). Diario de la guerra del cerdo. Buenos Aires: Emecé.

Bordieu, Pierre (1997). Meditations pascaliennes. París: Editions du Seuil.

Boyle, T. Coraghessan (2000). A Friend of the Earth. Londres: Bloomsbury.

Brown, Dan (2013). Inferno. Nova York: Doubleday.

Callenbach, Ernst (1990). Ecotopia. Nova York: Bantam Books.

- (1981). Ecotopia Emerging. Berkeley: Heyday Books.

Chamie, Joseph (2010). «Decoding Demography». Foreign Affairs, maig/juny, 2010.

ChesnaIs, Jean-Claude (1995). Le crépuscule de l'Occident. Démographie et politique. París: Robert Laffont.

Cincotta, Richard P. (2004). «The Next Steps for Environment, Population and Security». ESCP Report, 10, 24-29.

Cincotta, Richard P., Engelman, Robert i Anastasion, Danielle (2003). The Security Demographic. Population and Civil Conflicts after the Cold War. Washington, DC: Population Action International.

Cousteau, J. Y. (1991). «Environnement et développement: un pacte planétaire». Le Courrier de l'Unesco. París: novembre, 1991.

Domingo, Andreu (2008a). «Demodystopias: Prospects of Demographic Hell». Population and Development Review 34 (4), 725-745.

- (2008b). Descenso literario a los infiernos demográficos. Distopia y población. Barcelona: Anagrama. 
Ehrlich, Max (1972). The Edict. Nova York: Bantam Books.

Ehrlich, Paul R. (1968). The Population Bomb. Nova York: Sierra Club.

Ehrlich, Paul R. i Ehrlich, Anne (1990). The Population Explosion. Nova York: Touchstone Books.

Eмmотт, Stephen (2013). Ten Billion. Londres: Penguin Books.

Foucault, Michel (2006). Seguridad, territorio, población. Buenos Aires: Fondo de Cultura Económica.

Funuyama, Francis (1989). «The End of History?». The National Interest, estiu, 1989.

Gadamer, Hans-Georg (1977). Verdad y método. Fundamentos de una hermenéutica filosòfica. Salamanca: Sígueme.

Goldstone, Jack A. (2010). «The New Population Bomb. The Four Megatrends that Will Change the World». Foreign Affairs, gener/febrer, 2010.

Holling, C. S. (1073). "Resilience and Stability of Ecological Systems». Annual Review of Ecology and Systematics, 4, 1-23.

Huntington, Samuel P. (1993). "The Clash of Civilizations». Foreign Affairs, 72 (3), 22-49.

- (1996). The Clash of Civilizations and the Remaking of World Order. Nova York: Simon and Schuster.

- (2004). Who are We? The Challenges to America's National Identity. Nova York: Simon and Shuster.

Huxley, Aldous (2004). Brave New World/Brave New World Revisited. Londres: Harper Perennial.

Ishiguro, Kazuo (2005). Never Let Me Go. Londres: Faber and Faber.

James, P. D. (2006). The Children of Men. Nova York: Vintage Books.

Kuijsten, Anton (1999). "Demografiction». A: Kuijstein, Anton; Gans, Hans de; i Feijter, Henk de (eds.). The Joy of Demography... and Other Disciplines: Essays in Honour of Dirk Van de Kaa. Amsterdam: Thela Thesis, 83-102.

Laval, Christian i Dardot, Pierre (2010). La nouvelle raison du monde. París: La Découverte.

Lovelock, James (2007). The Revenge of Gaia. Londres: Penguin Books.

- (2010). The Vanishing Face of Gaia. Londres: Penguin Books.

Macpherson, Colin (1999). The Tide Turners. Queensland: Mopoke.

Meadows, Donella H., Meadows, Dennis L., Randers, Jorgen i Behrens III, William W. (1972). The Limits to Growth. Londres: Universe Books.

Meadows, Donella H., Meadows, Dennis L., Randers, Jorgen (1992). Beyond the Limits. Chelsea: Chelsea Green Publishing.

Meadows, Donella H., Randers, Jorgen, i Meadows, Dennis L. (2004). Limits to Growth. The 30-Year Update. Chelsea: Chelsea Green Publishing.

Notestein, Frank (1945). «Population - The Long View». A: Schultz, E. (ed.) Food for the World. Chicago: University of Chicago Press.

Pendleton, Don (1974). Population Doomsday. Nova York: Pinnacle Books.

Popper, Karl (1945). The Open Society and Its Enemies, Londres: Routledge.

Raspail, Jean (1973). Le Camp des Saints. París: Robert Laffont. Reimpressió: 2007.

- (2004). «La patrie trahie par la République». Le Figaro, 17, juny 2004.

SARtori, Giovanni i Mazzolenni, Gianni (2003). La terra scoppia. Sovrapopulazione e sviluppo. Milà: Rizzoli.

Shriver, Lionel (1994). Game Control. Londres: Faber and Faber.

- (2003). «Population in Literature». Population and Development Review, 29 (2), 153-162. 
Streeck, Wolfang (2011). "The Crises of Democratic Capitalism». New Left Review, 71 (setembre-octubre, 2001), 1-14.

Thoreau, Henry David (1854). Walden or Life in the Woods. Stilwell, Boston: Ticknor and Fields.

Vonnegut, Kurt (1953). «Tomorrow and Tomorrow and Tomorrow». Galaxy. Nova York: Delacorte Press.

- (1968). «Welcome to the Monkey House». Playboy. Nova York: Delacorte Press.

Wells, H. G. (1895). The Time Machine. Londres: Heinemann.

World Economic Forum (2012). Global Risks, 2012. Ginebra: World Economic Forum.

- (2013). Global Risks, 2013. Ginebra: World Economic Forum.

- (2014). Global Risks, 2014. Ginebra: World Economic Forum. 